\title{
"Baby Shark" as a Social and Artistic Phenomenon
}

\author{
Tea-Tereza Vidović Schreiber ${ }^{1}$, Vlaho Kovačević ${ }^{2, *}$, Dodi Malada $^{1}$ \\ ${ }^{1}$ Department of Early and Preschool Education, Faculty of Humanities and Social Sciences, University of Split, Croatia \\ ${ }^{2}$ Department of Sociology, Faculty of Humanities and Social Sciences, University of Split, Croatia
}

Received May 26, 2020; Revised July 27, 2020; Accepted August 10, 2020

\section{Cite This Paper in the following Citation Styles}

(a): [1] Tea-Tereza Vidović Schreiber, Vlaho Kovačević, Dodi Malada,, "'Baby Shark' as a Social and Artistic Phenomenon," Universal Journal of Educational Research, Vol. 8, No. 10, pp. 4449-4458, 2020. DOI: 10.13189/ujer.2020.081012.

(b): Tea-Tereza Vidović Schreiber, Vlaho Kovačević, Dodi Malada (2020). "Baby Shark" as a Social and Artistic Phenomenon. Universal Journal of Educational Research, 8(10), 4449-4458. DOI: 10.13189/ujer.2020.081012.

Copyright $\bigcirc 2020$ by authors, all rights reserved. Authors agree that this article remains permanently open access under the terms of the Creative Commons Attribution License 4.0 International License

\begin{abstract}
The aim of this paper is to present traditional nursery rhyme as a form easy to bring closer to children using the symbolic interaction method, through a presentation of the dance structure, which stimulates various activities. Nursery rhyme featuring text shown with movement, animation, and singing such as "Baby Shark" clearly indicates an additional arousal of certain meanings, sense and emotions in children. Therefore, nursery rhyme is shown in this paper as a general culture concept and a general context concept, which can be applied to encounters among individuals of different cultural or ethnic backgrounds. Regardless of the specifics of cultural background and the social situation involved, the nursery rhyme can become interculturally acceptable even in the context of the "new normality". Namely, employing an interdisciplinary approach within sociology, literature and kinesiology, the paper will show how "Baby Shark", in addition to games and content that is recognizable to children, e.g. role and position within the nuclear and the extended family, offers children, in moments of the global pandemic COVID-19, a sense of security at the level of recognizing the world of childhood which they belong to. If performed in a different environment, space, and context, this nursery rhyme can turn from a song with entertaining content to a song that raises morale, removes fear, and instills hope. Furthermore, showing children, as recipients, certain contents of the rhyme through movement results in an interaction of different meanings and a synthesis thereof into a new meaning with members of other (sub) cultures. This is additionally supported by the fact that this nursery rhyme, sang mostly in English, is very popular. However, due to the technologically more modern social communication model, because of which the rhyme is a
\end{abstract}

part of "secondary orality", language barriers are broken both in the original rhyme and in a number of its versions.

Keywords Baby Shark, Nursery Rhyme, COVID-19, Intercultural Competence, Dance Structure, Symbolic Interaction

\section{Introduction}

The starting point of this paper is that children are in touch with nursery rhymes ${ }^{1}$ from their earliest age. They are introduced to nursery rhymes as well as lullabies already within their family and after that in kindergartens and preschools. However, for a child to fully experience the beauty of oral literary forms, including the contemporary ones, it is necessary to bring such forms closer to children. This can be done through adaptations and dramatizations of texts, followed by kamishibai ${ }^{2}$ (as a combination of image and speech), in the context of stage expression, as well as dance as a special kind of art

\footnotetext{
${ }^{1}$ Nursery rhyme is a type of rhythmic speech, created mostly by children, with the purpose of counting (counting out, counting down, counting in, counting off, numbering) preceding a game (Gospodetić, 2015).

2 Kamishibai is an interdisciplinary art, and exactly this kind of storytelling model opens up a whole range of improvisations as well as new possible ways of learning the storytelling skills. Yet, this includes certain frameworks, which primarily relate to reduction of both images and words, more precisely, the image and the word are harmoniously complemented. This paper tries to point out the importance of childhood narrative with a special emphasis on oral literary forms (tongue twisters, poems, pravers, fables, fairy tales, legends, anecdotes, life stories, childhood stories, etc. (Vidović Schreiber, 2018).
} 
(Vidović Schreiber, 2015), which will be discussed in a special chapter.

The aim of this paper is two-fold:

1. to show the nursery rhyme "Baby Shark" as a process of social interaction with others involving gestures, conversation, and taking on the roles of members of the nuclear and the extended family within which the child feels safe. Namely, for the child's complete development and protection in the surrounding society, even in this "new normality", the content is important for the child at the level of recognizing herself/himself as a small being who feels protected both within the family and during the current COVID-19 pandemic.

2. to show the development of the child's identity orientation, which includes the influence of child's overall participation in fruitful symbolic communication activities on other social actors promoting reciprocity and cooperation in intercultural relations. In addition, the movements of the symbolic interaction of the dance structure evoke the need to emphasize the importance of the rhyme that contributes to identity safety and overall intercultural competence in children.

In this set-to-music nursery rhyme, there is a dance interpretation of the child and her/his family members, which enables a more complete experience of the family environment. Here, it is important to emphasize that children like to sing nursery rhymes, as their pronounced rhythm offers children the possibility of self-realization through a series of musical games, and the rhyme influences the development of speech and rhythm.

\section{2. "Baby Shark" in the Semantic Game of Symbolic Interaction of Social Actors}

The nursery rhyme "Baby Shark" is repetitive and it is precisely such counting poetics, which children find close to them, that makes it possible to approach certain meaningful contents that children gladly imitate and receive as a recognizable part of their childhood. The umbrella theme of this song is the role of the nuclear and the extended family, although different cultures offer different versions of the rhyme, conditioned by social and semantic meanings. Yet, the role and position of the child as a being in need of protection always remains clear, the rhyme thus arousing meanings, sense and emotions of the

\footnotetext{
${ }^{3}$ Baby Shark is a "catchy song" that managed to break into the list of top 40 hits in the UK, and is on the 38th place on Billboard's list of 100 greatest hits at the moment.

http://www.novilist.hr:8090/Zivot-i-stil/BABY-SHARK-Kako-je-naizgle d-obicna-djecja-pjesmica-postala-viralni-hit-koji-rusi-sve-rekorde (accessed April 3, 2020).
}

child.

The words such as baby mentioned in the title of the rhyme, followed by simple terms referring to family members like mama, papa, grandpa, grandma - make it easier for the little ones to get acquainted with the structure of the nuclear and the extended family. ${ }^{4}$ However, there are different forms of the family influenced by the current processes of globalization (social relations, processes, and systems) within cultural and identity determinants and spiritual life. In this sense, the importance of an individual's intercultural competence is the acquisition of behaviors and activities that enhance collaborative relationships with culturally or ethnically different individuals (Deardoff, 2009: 53).

For example, while the English version only lists shark family members, in the Korean version the baby shark's mother is "beautiful", the father is "strong", the grandmother is "kind", and the grandfather is "cool". Thus, the child consciously playing certain roles of family members builds her/his personality, or her/his "self", ${ }^{6}$ and through identifying with family members the child retains the identity of the nuclear or extended family and shares common forms (prejudice, family commitment, discrimination outside the family).

Namely, children's social world begins in their families, and language games model meanings, created, developed, modified, and changed in the current process of symbolic interaction within the family (Wiley, 1994: 63). The family community ultimately exists in a symbolic order, not in an objective reality, ${ }^{7}$ and as a young child's brain is formed to mimic behavior, it will quickly learn the usual rules (Hendrix, Palmer, Tashis \& Winner, 2013). An organized family structure is created in the child herself/himself, as the nursery rhyme theme is expressed in the game rules (Mead \& Dvornik, 2003).

Children learn by model, thus their speech model should be representative.

In the book "Stihovi u pokretu" ("Verses in Motion"), Velički and Katarinčić (2011) list six aspects related to

\footnotetext{
${ }^{4}$ The family is "a group of people directly related by kinship, with adult members taking responsibility for caring for children. (...) In almost all societies we can identify what sociologists, anthropologists call a nuclear family, in which two adults live in a household together with their own or adopted children. (...) When close relatives, apart from a married couple and their children, live in the same household or in a close and lasting relationship with each other, we are talking about an extended family" (Giddens, 2007: 173).

5 Here we can observe certain stereotypes in the characterization in works of children's literature.

${ }^{6}$ In sum, we can say that identity becomes an issue when the self ceases to be taken for granted (Delanty, 2018: 160). The modern understanding of the self is a social self that is formed in relationships of difference, not in unity and coherence (Delanty, 2018: 160), while Anthony Giddens argues that in the societies of late modems a new kind of individualism was created by which the self is greatly empowered but not necessarily emancipated (Giddens, 1990; 1991).

7 It is a form of "community awareness," and as such the community is "embraced in the perception of its boundaries," from which it follows that community is always a matter of "symbolic constructed reality" (Cohen, 1985: 13).
} 
finger games, we would add both hand and movement games in general, which undoubtedly affect children's development:

- emotional development because they arouse joy,

- motor development that encourages the development of fine motor skills, ${ }^{8}$

- $\quad$ sensory aspect refers to eye-hand coordination, i.e. connecting different sensory systems (it is especially important since humans have the ability to control their hands with the help of the eyes and we rely on the sense of sight very often and to a great extent),

- cognitive aspect related to the presentation of the course of action, causes and consequences,

- neuropsychological aspect (it stands out because it is responsible for the coordination of the left and right cerebral hemispheres, that is for the coordination and equal use of the left and right hands in finger games), and

- linguistic aspect emphasizes the importance of the rhyme for stimulating speech, because the brain cells in charge of speech are located in the same place as the mirror neurons responsible for the movement control system.

Language is a system of signs, it is comparable to the script, the alphabet for people having difficulties with speech and hearing, to symbolic rituals, to forms of politeness, to military signs, ${ }^{9}$ etc. (Saussure, 2000). To understand certain contents of the rhyme it is possible to observe language as a labyrinth of cultural signs, as the means and purpose of identities that are constantly re-constructed. ${ }^{10}$

Language as a system of signs is a semantic or linguistic fact whose rules are used by speakers to shape their messages (Kovačević, 2002: 14). Linguistics will remain within linguistic relations and the semiotic level of the verbal sign will then emerge from the linguistic context (Peleš, 1989, 73), and in pragmatic philosophical semantics it can take on the meaning of "language game", thus the

\footnotetext{
${ }^{8}$ The influence of manual movements on brain development was known as early as in $2^{\text {nd }}$ century $\mathrm{BC}$ in China, therefore Herljević and Posokhova (2007) point out that when the development of fine motor skills lags behind, the development of speech also lags behind.

9 There is also the example of the training of the US Marines, where the "Baby Shark" rhyme is used to raise morale and maintain the rhythm of the set military structures (https://youtu.be/7N4ChH5mvAo) (accessed July 3, 2020).

10 "Language changes the present-day world, nations and human lives due to the growth of communication at local, national, regional and supranational levels (Sun, 2013: 35). In this process, the English language imposed as an instrument of globalisation (the global language), which prevails in business communication and on the Internet as the most popular communication tool. Globalisation has become a popular term in political, economic, technological and scientific (thus sociological) discourse. Abercrombie. Hill \& Turner (2006: 167) point out that globalisation makes world increasingly homogeneous due to the contact among cultures and the increase in movements/traffic of people. information and goods, enabled by the development of technology for 'time and space compression' (ICT), traffic systems etc.)" (Kovacevic, Spetic \& Pleslic, 2018: 174).
}

sign would not be directly related to what it names but to the very linguistic context in which it is placed (Peleš, 1989: 54).

Culture as a system of signs available to every participant in the community is necessary for the interpretation of human action and meaning. Using them, human creates culture through the material needs of existence (housing, feeding, clothing, types of the economy), social needs of existence (kinship, family, rights, customs) and spiritual needs of existence (art, belief, philosophy).

Culture, therefore, is not limited to verbal communication. As a social phenomenon, it is learned because it is based on signs, symbols that each individual must learn in their meaning in order to be able to integrate into certain social groups in which her/his actions will be understandable to the whole group. Thus, there is a sense of identity that holds the whole group together (Kovačević, 2002: 14). "It follows from the above that signs and symbols reveal our own nature, which is symbolic and allows us to focus, to become more attentive to the reality that we reach through symbols, i.e. signs" (Kovačević, 2002: 33).

Although the game is the main means of expression in the rhyme, it is still possible that words of the rhyme do not have a meaningful connection, turning such a semantic game into a series of asemantic formations (Botica, 2013) thus creating a musical-acoustic-rhythmic atmosphere. ${ }^{11}$ In children's oral poetry, ${ }^{12}$ in addition to melodicity, early reception, rhythmic speech (pronunciation), its possible transformation and performance should be emphasized (Hameršak, Zima, 2015). Thus, art is also a game, in which the possibilities of the playful and the serious, the working and the ludic are realized in different measures (Golub, 1990). For children, all those possibilities are connected with the fact of perceiving symbols within which culture can be redefined as a complex system of definitions and corresponding plans of action that have been accumulated throughout human history.

Being exposed to rhyme is also an excellent strategy to help children develop phonological awareness (Mullen, 2017). Thus, language game offers children great auditory opportunities to learn the meaning of words as well as the sounds making words (Dunst, Meter \& Hamby, 2011; Bryant, Bradley, Maclean \& Crossland, 1989). In doing so, every word, sound, movement or person becomes a sign whose direct sensory perception is not directed to the cognition of a word, sound, movement or person, but allows our spirit to reach something else, which is hidden

\footnotetext{
${ }^{11}$ Semantic game begins to point to the ruling whole without taking us away from ourselves to something else; we actually stay in the semantic game, but we go back deeper into it and experience this whole vibrating through the rhythm.

${ }^{12}$ Nikolić (2015) also notes that rhymes as forms, throughout history, have often been "forcibly" classified as poetry or prose, while he classifies them into oral rhetorical genre.
} 
and invisible, and as such eludes our immediate sensory perception. The word, sound, movement, or person thus warns us, informs us, and contains an order that has "echoes", "resonances" in social life.

\section{3. "Baby Shark" as an Internalized Identity Symbol in Intercultural Relations}

Symbolic interactionism as one of the contemporary sociological theories drawing on the theoretical work of American sociologists (Kukić, 2004: 114) perceives the subtle game between society and individuals better than other sociological theories (Stryker, 1980). Developing herself/himself through the perceptions and control of others makes the child capable of independent action (Cooley, 1998). The process of developing a sense of self in terms of looking at one's image as a mirror of others reveals to children their own "self" and anticipates their actions. $^{13}$

Human's ability to create the culture and to transmit culture stems from a human's ability to sometimes manipulate symbols by engaging in symbolic interaction. Different performances of "Baby Shark" reflect the culture and dynamics of the performer's experience in the creative process, applying them to specific situations. "In that sense, if we want to understand the actions of others, regardless of whether we are laymen or sociologists, we must accept that their meaning lies in what their participants recognized as the meaning of their actions" (Afrić, 1988: 2).

Thus, the "Baby Shark" can occupy a special place in science through the study of intercultural relations and intergroup behaviors in particular through the identity orientations of the self (Deardoff, 2009: 54). "One of the major themes in postmodernist thought over the past twenty years concerns the identity of the self. The question "Who am I?" has returned today in a whole variety of contexts, including feminism, multiculturalism, ethnicity, and race" (Delanty 2018: 158).

Hence the new thinking of the community in modernity that seeks to reconstruct the classical sociological perspective of fetishizing the category of "society" reveals three key sources of modern dynamism (separation of time and space involving the process of growingly closer social relations and interactions between people living and working in different parts of the world, "raising up" and

\footnotetext{
13 Dragić (2008), dividing oral rhetorical forms into fables, toasts, counting and nursery rhymes, tongue twisters, blessings and curses, mentions Hektorović's "Fishing and Fisherman's Talk" as the first example of Croatian rhetorical form, which is extremely important for Croatian cultural heritage. Guided by the thought that we know little about our own as well as other people's tradition and culture, and that nursery rhymes as a part of oral rhetorical and author literary forms are certainly part of the identity of a nation's cultural creation, it is necessary to spark interest of future generations for it (Vidović Schreiber, 2015, 505).
}

moving social relations from local contexts of interaction to new contexts, reflexively arranging all social relations with the aim of improving it) (Haralambos and Holborn, 2002: 496)

A possible answer to the question "Who am I?" is offered in the symbolic activity of the meaning of the human spirit (Collins, 2005: 186-187). The symbol is therefore never a natural, but always a cultural sign, thus in the nursery rhyme the sign is freely chosen and, we would add, freely interpreted. On the other hand, it is always chosen on the basis of the fact that its nature or its properties contain elements that represent a certain analogy (inference by similarity) or coincidence with what should be symbolized in the rhyme (Kovačević, 2002: 34). In an attempt to express herself/himself through thoughts, feelings, words and actions, the child realizes that many life realities - that are unspeakable, that require an explanation for the inexplicable, to simplify the complex, to put in certain forms what by its nature has no limits, and does not support the mold require symbols as drivers, instigators, inventors and possible life support without which one cannot live as a human - the embodied spirit.

Given the inseparability of the personal and the social in these conceptions, the term identity is employed in rhymes as an individual's global identity. This holistic conception of identity is viewed in rhymes to serve as the general self-other orientation of an individual, that is, the routinized way or "personal schema" (Horowitz, 1991) with which individuals respond to external stimuli. As such, identity in rhyme analysis is regarded as the more or less enduring core constitution of personhood that influences the individual's intercultural behavior. The term cultural identity is employed throughout this analysis to refer to the group dimension of identity. It is used as a broad, inclusive concept that represents similar terms such as national, cultural, ethnolinguistic, racial, and religious identity (Deardoff, 2009: 54-55).

Different cultures ${ }^{14}$ foster different values through different symbols resulting in cultural diversity. In some cultures, monoculturalism is preferred, with a very high level of cultural homogeneity, while in most industrialized societies there is a greater level of cultural diversity, i.e. multiculturalism. Human as a cultural being who interprets her/his actions and meanings creates culture through the material needs of existence, the social needs of existence, and the spiritual needs of existence. In this way, certain social structures are created as forms of

\footnotetext{
${ }^{14}$ Often has it been possible to establish a false universalism of culture and the pernicious particularism of political identity in recent history, in the position between obiective social processes and the relationship of globalization within language, culture, and identity determinants of a value social context. In this sense, it is important to show how the factors of political power of the value social context successfully penetrate not only into the social but also into the intimate sphere of the social being. This shows the undisguised ideological enchantment of reality within the new cultural struggles for identity among different ways of life (Paić, 2005: 11)
} 
action and meaning realized in interpersonal interaction. Namely, looking at culture from the aspect of the production of meaning and sense, it should be noted that culture is more complex and richer than the available signs, thus in the signified there remains forever something outside of the sign, in which a symbol is a decisive and starting fact.

Cultural diversity is conditioned by differences in meaning and is linked to systems with other meanings of certain cultural structures and cultural identities. If language is one of the basic code systems, which is created under the influence of objective social processes for the purpose of communication, then symbols have another significant socio-cultural function in societies and social groups. In individuals, it is the function of identification and self-identification of the mentioned social and cultural entities (Skledar, 2002: 84).

Each culture is different from another, which in situations of marked diversity can lead to cultural shock. Due to the diversity of cultures in the world, it is necessary to study culture not based on comparison with one's own culture, i.e. ethnocentrically, but within itself, without comparison with other cultures. Nowadays, society and social actions are inevitably associated with the concept of globalization, due to the growing interdependence of different peoples, religions, and countries of the world (Giddens, 2007).

The basic question of the content of nursery rhymes is how to affirm the child's dimension of openness between objective social processes and the relationship of globalization within language, culture, and identity, affecting the understanding of the value social context of educators in the educational process of language. The answer is possible only outside the ideological and one-sided approach of ideological mobilization of consciousness and restraint of the entire human existence in a false world of even more false needs.

Therefore, the relationship of linguistic-literary identity determinants within the sense of nursery rhymes in understanding certain contents in the age of globalization as a "new paradigm" raises many questions:

Is the impact of globalization cancelling the nuclear and extended family and classical modern dualisms such as individual/collective, particular/universal, sacred/secular?

Is globalization diminishing and erasing certain features or characteristics in the field of culture, economy, and religion that do not suit it at a given time?

Is globalization a kind of coercion and a certain leveling of values, translating them into a special kind of political language, utilitarian and banalized, to which we are subjected (Matvejević, 2011: 222)?

And finally, is the process of globalization establishing and returning to historical, traditional, and local identities as spaces of permanent recognizability?

In this paper, the primacy of the individual is emphasized through two related identity orientations: the inclusiveness of the identity and the safety of the individual's identity in the overall ability to engage in collaborative intercultural relationships (Deardoff, 2009: 53-66). Therefore, this paper emphasizes the importance of rhyme in understanding identity as one of the intercultural competences and constructive relational engagement within globalization processes.

\section{4. "Baby Shark" - between Rhythm and Movement}

Given that each rhyme provides an opportunity to express rhythm and movement (Peteh, 2007: 20), "Baby Shark" is suitable to enable dance to correlate with the contents of other educational areas. Furthermore, dance especially emphasizes the primordial syncretism of music and movement, develops a sense of the aesthetics of movement, develops concentration, observation and memory, self-discipline and focusing, and encourages children to respect each other and cooperate through movement.

Rhymes, poems, and various verses make memory easier by using a large number of repetitions or rhymes. Such forms develop a sense of rhythm, intonation, tempo, etc. (Rade 2009: 29). Thus, "Baby Shark", due to its rhythmicity and sonority, accumulation of words, enumeration of elements and concepts that shape the structure, can be used in working with preschool children to practice memorization.

Aesthetic value (which is in addition questionable) and the planetary popularity of "Baby Shark" as a nursery rhyme, is reflected in the fact that it as a rhetorical form is skillfully realized as a rhythmic game, rhythmic whole, word game, type of onomatopoeia or form of children's creativity, which is complemented by movement, a form children always find close to them.

The most common methods of learning rhythm in children are achieved through nursery rhymes featuring movements of clapping hands, patting knees, and the like. Movements must be as natural and free as possible, for children to develop independence, creativity, and imagination. When choosing the music that children will dance to, attention should be paid to the song children are interested in, familiar songs, compelling, short, easy to remember while the song content should be appropriate to children's age (Lovrenović, 2016: 31). To illustrate the above, we attach the content and performance explanation of the "Baby Shark" song.

Baby shark, do do, do do do do

Baby shark, do do, do do do do

Baby shark, do do, do do do do

Baby shark

*(rhythmic movements, joining only two fingers symbolically represents a simple motor movement of the 
child, resulting in the visualization of a small, gentle child)

Mama Shark, do do, do do do do Mama Shark, do do, do do do do Mama Shark, do do, do do do do Mama Shark

* (clapping movements show mom, encouragement, motivation, applause)

Papa Shark, do do, do do do do Papa Shark, do do, do do do do Papa Shark, do do, do do do do Papa Shark

* (stronger and bold movements, with maximally stretched arms, describe dad, strength and safety of the family)

Grandma Shark, do do, do do do do

Grandma Shark, do do, do do do do

Grandma Shark, do do, do do do do

Grandma Shark

* (gentler and softer movements with clenched fists, consideration and careful folding of the hands indicate the care of an older and fragile family member)

Let's go hunt

Doo doo, doo doo doo doo

Let's go hunt

Doo doo, doo doo doo doo

Let's go hunt

Doo doo, doo doo doo doo

Let's go hunt

* (circular forward movements of the arms symbolize hunting, gradually involving in the action the torso, arm muscles, and muscles of the shoulder girdle)

Run away

Doo doo, doo doo doo doo

Run away

Doo doo, doo doo doo doo

Run away

Doo doo, doo doo doo doo

Run away (ah!)

* (simulation of the movement of running and escaping from danger activates the complete musculature, raising the functional abilities in a dynamic and expressive way; accelerated rhythmic structures are intertwined, greatly contributing to the development of a sense of rhythm that ultimately manifests itself by running in all directions)

Safe at last

Doo doo, doo doo doo doo

Safe at last

Doo doo, doo doo doo doo

Safe at last
Doo doo, doo doo doo doo

Safe at last (phew!)

*(the quiet part of the finale, the sudden interruption of the flow of movement creates an image of peace and safety in the end; there is a release of tension and the movements become soft and gentle, which is manifested through a calm posture with a light waving)

It's the end

Doo doo, doo doo doo doo

It's the end

Doo doo, doo doo doo doo

It's the end

Doo doo, doo doo doo doo

It's the end

Source: _Musixmatch

Lyrics by: Jahmeelah Lamb-rahming

\subsection{Analysis of the Movements Accompanying the "Baby Shark" Song}

The "Baby Shark" song is written in a two-quarter measure and has a simple melody awakening a cheerful mood, with the tempo accelerating towards the end of the song. The lyrics of the song are in English making the song good for foreign language acquisition, knowing that preschool children, as we have already mentioned, are in a favorable period to master their mother tongue as well as foreign languages.
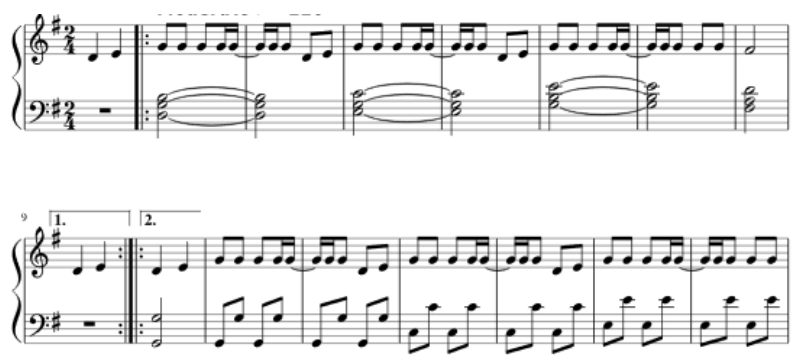

Figure 1. Musical notation of the song "Baby Shark" for piano ${ }^{15}$

This song offers various opportunities and activities to be carried out with children. Since the song is accompanied by a video, ${ }^{16}$ it is possible to demonstrate to the children the movements from the video when listening to music. The dance moves accompanying "Baby Shark" require locomotor coordination, balance, and a sense of rhythm. For example, dancing three-year-olds will be happy to play with some of the formal elements of movement: jumping, rolling, various types of locomotion will be a real joy for

\footnotetext{
${ }^{15} \mathrm{https} / /$ musescore.com/bluebook83/scores/167520 (accessed August 15, 2020).

${ }^{16}$ Which points to a new way of transmitting oral forms, and as such is a part of secondary orality.
} 
them. As growing up is a dynamic process, at the age of four it will be easier to master the work process if designing the appropriate content along with the activity (Lovrenović, 2016).

The activity accompanying "Baby Shark" allows children to express and recognize their own and other people's emotions. For younger children, music itself is an excellent motivation to move, while older children understand the connected movements as a symbolic expression, or representation of things, phenomena, or behavior using artistic movement. The educator can be creative and enrich the activity with other dance structures. These structures must be simple and are ideal if they are close to the natural forms of walking, jumping, etc. The children will find new dance moves and elements that suit them. The children should be encouraged and supported in carrying out the activity. It is possible to collaborate and jointly create new choreography, thus creating a group identity that gives children a sense of belonging and acceptance, satisfying the need for power, and not of isolation, loneliness and abandonment (Lovrenović, 2016), which was discussed in the first part of the paper.

Human beings are capable of "self-reflexive behavior", namely, to take an attitude towards themselves and others and to determine their interaction accordingly. In this sense, human beings behave in a disposed manner, and self-reflexive behavior requires manipulation of symbols, words, meanings, and various languages, in short, it requires symbolic interaction (Afrić, 1988: 2-3).

In the example of dance activities accompanying the "Baby Shark" song, it is possible to list a number of benefits for children. Carrying out activities using dance structures has an impact on the child's overall anthropological status, i.e. on the following: motor traits, functional traits, morphological traits, social status, and conative traits. Šumanović et al. (2005) believe that by organizing activities that integrate music and dance structures, natural movements gain an aesthetic dimension and become the contents of dance expression of children and the young in more complex dance forms of folk, social and artistic dance, in aesthetic gymnastics and other contemporary movement forms through which they express their personality in a creative and original way. Steps express the values of notes by duration, and hand movements express stressed and unstressed parts of the bar, that is, the bar metric structure. The next procedure in the processing of these contents is to connect and improve movement and music, striving for movement expression, thus encouraging children's creative dance expression. Movements accompanying music are further connected into rhythmic units, stylized, and performed in various formations and forms of children's dance games (Lovrenović, 2016).

\subsection{Nursery Rhyme as a Demonstration of Rhythm with Movements}

A nursery rhyme is a short song, a means to play, an incentive to play, a complement to the game but also it is a game in itself. It is often the source of new ideas. It allows inventing new funny words and new movements. It is recited in one tone, and we distinguish them according to length, melody, rhythm, occasion, mood, and space. Speech denotes text, and hand movement a measure. Speech structures based on rhymes and rhythm, while paying attention to rhythm, intonation, pause, gestures and body language (Šmit, 2001), are accessible to preschool children because they show elementality, brevity and simplicity. Their syllables - often composed of one vowel and two consonants - are easy to pronounce. There are several types of nursery rhymes that are categorized by separate criteria, by content and form, and by their authors (children, adults). According to these criteria, they are divided into two categories (Jurišić, Palmić, 2002), e.g. by performance (spoken and sung) and by content (concrete, nonsense, and combined). Namely, in the nursery rhymes, the rhythm is demonstrated: with the fingers, feet, hands, or the whole body, and can be expressed by fingers snapping, thus developing kinesthetic sensitivity, hearing and motor skills in the child. Pronunciation with movement can be expressed by clapping, waving, bouncing, with the use of various instrumental aids such as drums, rattles, and percussion (Peteh, 2007). This can be realized in an institutionally organized education or, as previously mentioned, in the family. Furthermore, every content that we present to children, including rhymes, must be described and performed in a way appropriate for children's age (Vlašić, Oreb and Horvatin Fučkar, 2007: 242). The movements applied in the choreography are simple, repeated several times and must not be alternated too quickly. More attention needs to be paid to the various formations and changes in them. Songs (featuring choreography) should be chosen based on their text and melody which refer to the characters that the children represent through their dance. When choosing the type of dance, it is important to offer the child (Vlašić, Oreb and Horvatin-Fučkar, 2007) a direction in which they will be able to focus and specialize in a certain type of dance, according to their preferences, abilities and desires.

\section{How "Baby Shark" Defeated Covid-19}

One of the latest notable performances of "Baby Shark" is the performance of police officers in Andorra who decided to go out into the streets and dance to the "Baby Shark" song to motivate and entertain children and fellow citizens in a hard time of self-isolation and quarantine caused by the COVID19 global pandemic. ${ }^{17}$ The police

\footnotetext{
${ }^{17}$ https://youtu.be/OGH63Cp5vHY (accessed July 8, 2020).
} 
officers showed that in the time of the "new normality" they can take the rhyme to the streets, the same streets that belong(ed) to children.

Using dance movements, singing and playing the purposefully chosen "Baby Shark" rhyme, they wanted to achieve a sense of, unfortunately somewhat disturbed, security, in children. This again brought to the fore the infectious and entertaining features of the song and most importantly, the features recognizable to members of different cultures and subcultures, not only in Andorra but also more broadly, conditioned by the modern model of spreading "secondary orality," that is, through modern media.

At this moment, the song "Baby Shark" outgrows its entertaining characteristic and becomes a song that due to its recognizability and simplicity, both in text and dance expression, becomes a means of providing psychological help. Once again in history, we are witnessing the moment that the indomitability of the human spirit is reflected in creativity. Human's ability to take on roles and create situations comes from the fact that human is a creative being, a being of practice in which she/he can engage in symbolic interaction of identity orientation in different social contexts.

\section{Conclusions}

Nursery rhymes contribute greatly to learning through play, which is voluntary learning, unobtrusive, permanent, imperceptible, without coercion (Peteh, 2003: 13), thus through rhymes and their interpretations the child gets acquainted with different contents. Nursery rhymes are present in all cultures of the world, yet culture is not limited to verbal communication. Namely, it is also learned as a social phenomenon, because it is based on signs, symbols that each individual must learn in their meaning in order to integrate into certain social groups in which her/his actions will be understandable to the whole group. Rhyme is a rhetorical form with respect to the whole context in which it is performed influencing the choice of the appropriateness of figurative speech. Therefore, it can be said from the position of oral literary rhetoric "that rhetoric is a system of figures" (Genette, 1985: 52). Furthermore, an important factor of rhetorical forms is convincing the recipient of a certain order of ideas and thoughts, ${ }^{18}$ so other properties of linguistic expression are subordinated to it, namely vocabulary, syntax, style, tone, and the task of presentation. Also, in dance, there are several educational goals of dance structures: to develop in children the aesthetic culture of movement in all its parts: beautiful posture, orientation in space, expression-emotionality in

\footnotetext{
${ }^{18}$ This can be compared with the so-called automatic writing, i.e. a lack of reason control.
}

movement, the musical expression: measure and rhythm. This paper showed:

1. how the "Baby Shark" illustrates through movement the nuclear and the extended family, the position of the members and the hierarchical relationship precisely according to the order of guidance and to the structure and dynamics of the movements performed by the child. The child can replace their "self" with others' "self", through a comparative example of the song "Baby Shark" children can illustrate others by taking over their role, through playing. Šimunović et al. (2005: 44) describe how when processing the content of dances, we start with simple movements that do not differ in structure from natural forms of movement (walking, jumping, turning), which is evident in the example of the selected rhyme, in tempo, dynamics, melody, sense of tone and movement and the free creativity of movement and music. For preschoolers, the choice of the song "Baby Shark" ${ }^{19}$ is also acceptable in the kinesiological context, as it can feature simple dance structures, which is shown in this paper through descriptions of movement. Movement is a natural reaction to the speech, which is visible in children from their earliest age. The child develops various cognitive and motor abilities, a sense of aesthetics and beauty, and the freedom to express one's own experience of the surrounding world. Furthermore, the child develops a positive image of herself/himself, learns about herself/himself in space and takes on group identity (if the activity is carried out with a group of children). Through this activity children can learn words of a foreign language and generally this activity gives them a feeling of happiness.

2. how the content of the song "Baby Shark" has changed through different historical contexts resulting in a number of its variants, which further achieved popularity, not only among the younger population but also among adults. Namely, one of the characteristics of this rhyme is that it is adaptable, and "Baby Shark" is a classic example of a repetitive song which allows singers to insert their own thoughts into the lyrics.

This is supported by the fact that "Baby Shark," which is most often in English, in different countries and different cultures, opens the possibility for rhymes - in a new modern and technologically acceptable communication process (as part of secondary orality) - to destroy language barriers, because in understanding certain contents of the rhyme, the same content is illustrated to the recipients through movement, enabling (them) an interaction with different meanings and a synthesis thereof into a new

\footnotetext{
${ }^{19}$ Link to the song: https://www.youtube.com/watch?v=XqZsoesa55wn (accessed July 2, 2020). .
} 
meaning with members of other (sub) cultures.

This interdisciplinary paper confirms the hypothesis that "Baby Shark," in addition to entertainment and game, in the moments of the global pandemic COVID-19, can enable security to children at the level of recognizing the world which they belong to. If performed in a different environment, space, and context, this nursery rhyme can turn from a song with entertaining content to a song that raises morale, removes fear, and instills hope.

The self has become increasingly reflexive in the sense that an individual's identity has increased only through supervision and self-control. This experience, according to Delanty, reveals the essence of postmodern sensibility, namely the feeling of insecurity, unpredictability and uncertainty both in the world and in the identity of the self (Delanty, 2018: 158).

The symbolic activity of the human spirit despite differences in identities, age groups, linguistic diversity, as can be seen in the case of the "Baby Shark", breaks down all barriers and becomes a common and unique dance game in the current processes of globalization, even in the emerging pandemic, because none of us can truly know ourselves being "closed in ourselves" due to a series of accumulated negative emotions.

Symbolic interaction as a method is not only applicable in sociology but also in other disciplines, such as literature and kinesiology, and this has been shown in this paper on the example of "Baby Shark".

Thus, the paper reaffirmed that literature and dance as parts of the culture and language of a society, through globalization, in which symbols transcend individual societies, can work together to create an acceptable and a more tolerant world for children.

\section{REFERENCES}

[1] N. Abercrombie, N. Hill, B. S. Turner, The Penguin Dictionary of Sociology, Penguin Books, London, England, 2006.

[2] V. Afrić, Simbolički interakcionizam, Revija za sociologiju, vol. 19 , no. 1-2, 1-13, 1988.

[3] S. Botica, Povijest hrvatske usmene književnosti, Školska knjiga, Zagreb, 2013.

[4] P. E. Bryant, L. Bradley, M. Maclean, J. Crossland. Nursery rhymes, phonological skills, and reading. Journal of Child Language, 16, 404-428, $1989 . \quad$ doi: $10.1017 / \mathrm{S} 0305000900010485$.

[5] P. A. Cohen, The Symbolic Construction of Community: Routledge, London, New York, 1985.

[6] R. Collins, Interaction Ritual Chains, Princeton University Press, Princeton, Oxford, 2005.

[7] C. H. Cooley, On self and social organization, University of Chicago Press, Chicago, 1998.
[8] D. K. Deardorff, E. Jones, Intercultural competence, Sage, Thousand Oaks, 2009.

[9] G. Delanty, Community, Routledge London, New York, 2018.

[10] C. J. Dunst, D. Meter, D. W. Hamby, Relationship between young children's nursery rhyme experiences and knowledge and phonological and print-related skills, Center for Early Literacy Learning, 4(1), 1-12, 2011.

[11] G. Genette. Figure. Transl. M. Miočinović, "Vuk Karadžić," Beograd, 1985.

[12] A. Giddens, Modernity and self-identity: Self and society in the late modern age. Stanford: Stanford University Press, 1991.

[13] A. Giddens, Sociologija, Globus, Zagreb, 2007.

[14] A. Giddens, The consequences of modernity, John Wiley \& Sons, 2013.

[15] I. Golub, Prijatelj Božji, Naprijed, Zagreb, 1990.

[16] H. Gospodetić, Metodika glazbene kulture za rad u dječjim vrtićima 1, Mali profesor, Zagreb, 2015.

[17] G. Jurišić, R. Sam Palmić, Brojalica, snažni glazbeni poticaj, Adamić, Rijeka, 2002.

[18] M. Hameršak, D. Zima, Uvod u dječju književnost, Leykam international, Zagreb, 2015.

[19] M. Haralambos, M. Holborn, Sociologija. Teme i perspektive, Golden marketing, Zagreb, 2002.

[20] R. E. Hendrix, K. Z. Palmer, N. Tashis, M. G. Winner, The incredible flexible you: A social thinking curriculum for the preschool and the early elementary years, CA: Think Social, San Jose, 2013.

[21] I. Herljević, I. Posokhova, Govor, ritam, pokret, Ostvarenje d.o.o, Lekenik, 2007.

[22] M. Horowitz, Person schemas. In: M. Horowitz (Ed.), Person schemas and maladaptive interpersonal patterns (pp. 13-31), University of Chicago Press, Chicago, 1991.

[23] V. Kovačević, Kršćanski ethos, Život između Boga i čovjeka u činu - znaku, Diplomski rad, Sveučilište u Zagrebu, Zagreb, 2002.

[24] V. Kovacevic, M. Spetic, M. Pleslic, Language as a social phenomenon in a global context: Implications for teaching practice. New Trends and Issues Proceedings on Humanities and Social Sciences, 5(3): 173-182, 2018, doi: 10.18844/prosoc.v 5i3.3922.

[25] S. Kukić, Sociologija: teorije društvene strukture, Sarajevo Publishing, Sarajevo, 2004.

[26] M. Lovrenović, Plesne strukture u predškolskom odgoju. Sveučilište Jurja Dobrile u Puli, Fakultet za odgojne i obrazovne znanosti, Pula, 2016.

[27] M. Marić, D. Nurkić, Uloga odgajatelja u poticanju dječje ekspresivnosti pokreta, Dijete, vrtić, obitelj: Časopis za odgoj i naobrazbu predškolske djece namijenjen stručnjacima i roditeljima, 20 (75), 16-18, 2014.

[28] P. Matvejević, Muke s identitetima, in: N. Skledar (ed.), Esadu Ćimiću u čast, Zbornik radova povodom 80 godina života, Sveučilište u Zadru, Zadar, 221-223, 2011. 
[29] G. H. Mead, S. Dvornik. Um, osoba i društvo: sa stajališta socijalnog biheviorista, Naklada Jesenski i Turk, Zagreb, 2003, (ed. orig. Mead, G. H. Mind, self and society (vol. 111). University of Chicago Press, Chicago, 1934).

[30] G. Mullen, More than Words: Using Nursery Rhymes and Songs to Support Domains of Child Development, Journal of Childhood Studies, 42(2), 42-53, 2017.

[31] Ž. Paić, Politika identiteta: kultura kao nova ideologija, Antibarbarus, Zagreb, 2005.

[32] G. Peleš, Priča i značenje: Semantika pripovjednog teksta, Naprijed, Zagreb, 1989.

[33] M. Peteh, Zlatno doba brojalice, Alinea, Zagreb, 2007.

[34] M. Peteh, Radost stvaranja. Alinea, Zagreb, 2003.

[35] R. Rade, Stihovi, pjesmice i brojalice su poput udice, Dijete, vrtić, obitelj, vol. 56, 2009.

[36] J. Sun, Globalization and language teaching and learning in China. International Journal on Integrating Technology in Education (IJITE), XX, 35-42, 2013.

[37] N. Skledar, Osnove znanosti o kulturi. Visoka škola za poslovanje i upravljanje s pravom javnosti "Baltazar Adam Krčelić”, Zaprešić, 2002.

[38] F. De Saussure, T. De Mauro, V. Vinja, A. Kovačec, Tečaj opće lingvistike, ArtTresor naklada, Zagreb, 2000.

[39] S. Stryker, Symbolic Interactionism: A Social Structural Version. The Blackburn Press, Caldwell \& New Jersey, 1980.

[40] M. B. Šmit, Glazbom do govora, Naklada Haid, Zagreb, 2001.

[41] Šumanović, M., Filipović, V., Sentkiralji, G., Plesne strukture djece mlađe školske dobi, Život i škola: časopis za teoriju i praksu odgoja i obrazovanja, 2005.

[42] V. Velički, I. Katarinčić, Stihovi u pokretu, Alfa, Zagreb, 2011.

[43] J. Vlašić, G. Oreb, M. Horvatin-Fučkar, Prednosti primjene plesa u radu s djecom predškolske dobi, in: M. Andrijašević (ed.), Sport za sve u funkciji unapređenja kvalitete života, Kineziološki fakultet Sveučilišta u Zagrebu, Zagreb, 239-244, 2007.
[44] N. Wiley, The Semiotic Self. University of Chicago Press, Chicago, 1994.

\section{Websites}

[45] M. Dragić, Poetika i povijest hrvatske usmene književnosti (fakultetski udžbenik), akademska godina 2007/08. Filozofski fakultet u Splitu, Split, 2008 . http://inet1.ffst.hr/images/50013808/

Dragic.Poetika.Povijest. pdf (accessed March 9, 2020).

[46] D. Nikolić, Mali, sitni, jednostavni, govornički ili jednostavno - retorički: povijest naziva i koncepata usmenoretoričkih žanrova u hrvatskoj folkloristici, Narodna umjetnost, $\quad 52 \quad$ (2), 163-178, 2015, https://doi.org/10.15176/vol52no208 (accessed March 9, 2020).

[47] https://musescore.com/bluebook83/scores/167520 (accessed August 15, 2020)

[48] http://www.novilist.hr:8090/Zivot-i-stil/BABY-SHARK-Ka ko-je-naizgled-obicna-djecja-pjesmica-postala-viralni-hit-k oji-rusi-sve-rekorde (accessed April 3, 2020).

[49] T. T. Vidović Schreiber, Tradicijska kazivanja i scenski izraz djece predškolske dobi, Školski vjesnik, 64 (3), 504-517, 2015. downloaded from https://hrcak.srce.hr/151384 (accessed March 13, 2020).

[50] T. T. Vidović Schreiber, Kamishibai - a New Narrative Context of Oral Literature in Working with Children of Preschool Age, in: Čepeljnik, M. (ed.) Umetnost kamišibaja [Elektronski vir]: zbornik prispevkov $=$ The art of kamishibai: proceedings, Slovenski gledališki inštitut, Ljubljana, 225-236, 2018.

[51] Herbauts, A. (2000). Was macht der Mond in der Nacht? Oetinger, Online available at https://www.amazon.com/Was-macht-Mond-Nacht-Ab/dp/ 3789166030 (accessed March 9, 2020).

[52] https://youtu.be/7N4ChH5mvAo (accessed July 3, 2020)

[53] https://youtu.be/OGH63Cp5vHY(accessed July 8, 2020)

[54] https://www.youtube.com/watch?v=XqZsoesa55w - link to the "Baby Shark" song (accessed July 2, 2020) 